\title{
USE OF SELECTED METAL IONS FOR THE SEPARATION OF PEPTIDES ISOLATED FROM THERMALLY PROCESSED STRING BEANS
}

\author{
Monika Karaś, Barbara Baraniak \\ Chair of Biochemistry and Food Chemistry \\ University of Life Sciences in Lublin
}

\begin{abstract}
Recent years have witnessed growing interest in research on the structure and properties of proteins and peptides as physiologically active dietary components. The above has spurred a new interest in the isolation of animal, plant and microbiological peptides and investigation of their biological activity. The isolation and separation of protein and peptide mixture is not an easy procedure. Immobilised Metal Ion Affinity Chromatography (IMAC) is increasingly often used in this process. Affinity chromatography relies on the specific interactions between amino acids, their reactive groups in peptides and metal ions. The objective of this study was to determine whether copper and nickel ions can be used for the separation of peptides isolated from string beans than had been blanched and heated in a microwave oven. In this study, peptides extracted with $1 \%$ trichloroacetic acid (TCA) from string beans that had been blanched and heated in a microwave oven, were separated by chromatography on columns with copper and nickel ions immobilised through iminodiacetic acid (IDA). Peptide concentrations of the separated fractions were determined. Peptides found in string beans had similar affinity for metal ions in the $\mathrm{Cu}>\mathrm{Ni}$ sequence, with selectivity in the $\mathrm{Ni}>\mathrm{Cu}$ sequence. Microwave heating of string beans decreases the peptide content of extracts isolated with $1 \%$ TCA. The resulting changes are dependent on the duration of the process and the type of heating medium. Affinity chromatography with the use of metal ions immobilized to iminodiacetic acid (IDA)-Sephadex G-25 may be successfully used for the separation of peptides isolated from string beans.
\end{abstract}

Key words: peptides, IMAC, metal ions, string beans.

dr Monika Karaś, Chair of Biochemistry and Food Chemistry, University of Life Sciences in Lublin, Skromna 8, 20-704 Lublin, e-mail: monika.karas@up.lublin.pl 


\title{
WYKORZYSTANIE WYBRANYCH JONÓW METALI W PROCESIE ROZDZIALU PEPTYDÓW IZOLOWANYCH Z FASOLI SZPARAGOWEJ PODDANEJ OBRÓBCE TERMICZNEJ
}

\begin{abstract}
Abstrakt
W ostatnich latach obserwuje się coraz większe zainteresowanie badaniem struktury oraz właściwości białek i peptydów jako fizjologicznie aktywnych składników diety. W związ$\mathrm{ku} \mathrm{z}$ powyższym wzrosło zainteresowanie izolowaniem i badaniem biologicznie aktywnych peptydów pochodzenia zwierzęcego, roślinnego oraz mikrobiologicznego.

W skomplikowanym procesie rozdziału i izolowania mieszanin białek i peptydów coraz szersze zastosowanie znalazła chromatografia powinowactwa na unieruchomionych jonach metali - IMAC (Immobilized Metal Ion Affinity Chromatography). Chromatografia powinowactwa wykorzystuje specyficzne oddziaływania między aminokwasami oraz ich reaktywnymi ugrupowaniami w peptydach a jonami metali. Celem pracy było zbadanie przydatności jonów miedzi i niklu w procesie rozdziału peptydów izolowanych z fasoli szparagowej poddanej blanszowaniu i ogrzewaniu mikrofalami. Fasolę szparagową poddano odpowiedniej obróbce cieplnej (blanszowanie i ogrzewanie w kuchence mikrofalowej), a z uzyskanego surowca ekstrahowano peptydy $1 \%$ kwasem trójchlorooctowym (TCA) Następnie przeprowadzono rozdział chromatograficzny na kolumnach $\mathrm{z}$ unieruchomionymi jonami niklu i miedzi poprzez kwas iminodioctowy (IDA). W otrzymanych frakcjach oznaczono zawartość peptydów. Peptydy obecne w fasoli szparagowej charakteryzowały się zbliżonym powinowactwem do jonów metali, co przebiegało w kolejności $\mathrm{Cu}>\mathrm{Ni}$, natomiast selektywność układała się w kolejności $\mathrm{Ni}>\mathrm{Cu}$. Ogrzewanie fasoli szparagowej obniża poziom peptydów w ekstraktach izolowanych 1\% TCA. Zmiany uzależnione sa od czasu trwania procesu i rodzaju zastosowanego czynnika grzewczego. Metoda chromatografii powinowactwa z wykorzystaniem unieruchomionych jonów metali na schelatowanym kwasem iminodioctowym (IDA) żelu Sephadex G-25 może być z powodzeniem stosowana do rozdziału peptydów izolowanych $\mathrm{z}$ fasoli szparagowej.
\end{abstract}

Słowa kluczowe: peptydy, IMAC, jony metali, fasola szparagowa.

\section{INTRODUCTION}

Increasing interest in the properties of proteins and peptides as bioactive dietary components has prompted further investigations into the isolation and activity of peptides of animal, plant and microbiological origin. It is not easy to select a technique appropriate for the separation of physiologically active peptides and proteins from impurities, and to ensure optimum isolation conditions so as to obtain a product with the highest biological activity.

Immobilised Metal Ion Affinity Chromatography (IMAC) relies on specific interactions between amino acids, their reactive groups in proteins and peptides and „transitory” metal ions, in particular $\mathrm{Cu}^{2+}, \mathrm{Zn}^{2+}, \mathrm{Ni}^{2+}, \mathrm{Co}^{2+}$, $\mathrm{Fe}^{3+}$ (CHAGA 2001). These ions are immobilised by a chelating compound on the bed, forming specific adsorbents which bind proteins and peptides. 
Protein affinity for metal ions is determined by numerous factors, including protein structure, type of chelating compound, $\mathrm{pH}$, type of solvent, presence of salt and competitive ligands or type of metal ions. The chelating compound on the bed (without immobilized metal ions) can be applied for removing metal ions, which are contained in edible parts of some fresh vegetables or aquatic plants (BosiaCKI, TYKsiŃSKI 2009, SEnZE 2009).

The objective of this study was to determine whether copper and nickel ions can be used for the separation of peptides isolated from string beans that had been blanched and heated in a microwave oven.

\section{MATERIALS AND METHODS}

Frozen pods of dwarf, green-podded string bean cv. Fana were used in the study. String beans were blanched at $90^{\circ} \mathrm{C}$ and heated in a microwave oven (Philips/Whirlpool - model 606), used 3 power range 500, 750 and 900 Watts. The heating process was carried out for 2, 4, 6, 8 and $10 \mathrm{~min}$.

Peptides were extracted from well-homogenized string bean pods with $1 \%$ trichloroacetic acid (TCA). Homogenate of $1 \mathrm{~g}$ sample of heated string beans was stirred with a magnetic stirrer with $10 \mathrm{ml}$ of $1 \%$ TCA $(\mathrm{pH} 1,4)$ for 2 hours at room temperature. The solid fraction was separated by centrifugation at $4000 \mathrm{rpm}$ for $15 \mathrm{~min}$. The collected extracts were separated by immobilized copper and nickel ion affinity chromatography.

\section{Gel preparation for peptide separation by IMAC}

Sephadex G-25 medium was mixed with a solution containing $0.0375 \mathrm{~g}$ $\mathrm{NaBH}_{4}, 10 \mathrm{~cm}^{3} 2 \mathrm{M} \mathrm{NaOH}$ and $1 \mathrm{~cm}^{3}$ of epichlorohydrin. The suspension was mixed slowly for 2 hours at room temperature, and $10 \mathrm{~cm}^{3}$ of $2 \mathrm{M}$ $\mathrm{NaOH}$ and $5 \mathrm{~cm}^{3}$ of epichlorohydrin solutions were gradually added during this time. The mixture was left overnight to complete the reaction. The gel was washed on a Büchner funnel and dried. The dried gel was mixed with $25 \mathrm{~cm}^{3}$ of a solution containing $5.3 \mathrm{~g} \mathrm{Na}_{2} \mathrm{CO}_{3}, 2.5 \mathrm{~g}$ iminodiacetate acid (IDA) and $0.03 \mathrm{~g} \mathrm{NaBH}_{4}$. The suspension was left overnight at $60^{\circ} \mathrm{C}$, being stirred slowly from time to time. After 24 hours, the gel was washed with distilled water followed by diluted acetic acid and distilled water again, to neutralize the $\mathrm{pH} .50 \mathrm{ml}$ of a solution containing copper (nickel) ions at a concentration of $1 \mathrm{mg} \mathrm{cm}^{-3}$ was added to the gel. Next, the bed was transferred to a $1.5 \mathrm{~cm}$ diameter and $12 \mathrm{~cm}$ long column. The column was equilibrated with $40 \mathrm{~cm}^{3}$ of a $0.05 \mathrm{M}$ solution of Tris-HCl buffer, $\mathrm{pH} 7.5$. A $2 \mathrm{~cm}^{3}$ sample was applied to a glass column packed with gel, and fractions 1-36 were eluted with a $\mathrm{pH}$ gradient of Tris-HCl buffer: 7.5, 5.5, 4.5 and back to 7.5 (adjusted with EDTA-fraction 37-70). $4 \mathrm{~cm}^{3}$ fractions were collected at a flow rate of $40 \mathrm{~cm}^{3}$ hour $^{-1}$. 
The peptide content was determined spectrophotometrically with trinitrobenzesulfonic acid (TNBS), according to the Habeeb's method (HABEEB 1966) modified by ADLER-NISSEN (1979). Leucylglycine were used as standards $(340 \mathrm{~nm})$.

\section{RESULTS AND DISCUSSIONS}

Non-ionizing electromagnetic radiation induces specific intermolecular interactions which during traditional cooking occur at a much slower rate, or are not observed at all. Recent research focuses on untypical changes in the structure of saccharide and protein molecules, activation of certain enzymes, the change in the configuration of amino acids from the naturally occurring left-handed to right-handed, and changes in the structure of fatty acid molecules induced by free radicals. These processes proceed much faster during microwave heating. Microwave irradiation causes rapid dipole reorientation and hydrogen bond breaking, and creates molecular friction (SuRówKA 1994). The thermal processing of string beans resulted in a significant decrease in the content of peptides (extracted with 1\% TCA) obtained by chromatographic separation, regardless of the type of metal ions immobilized on the column (Figures 1,2). Additional fractions of peptides showing high

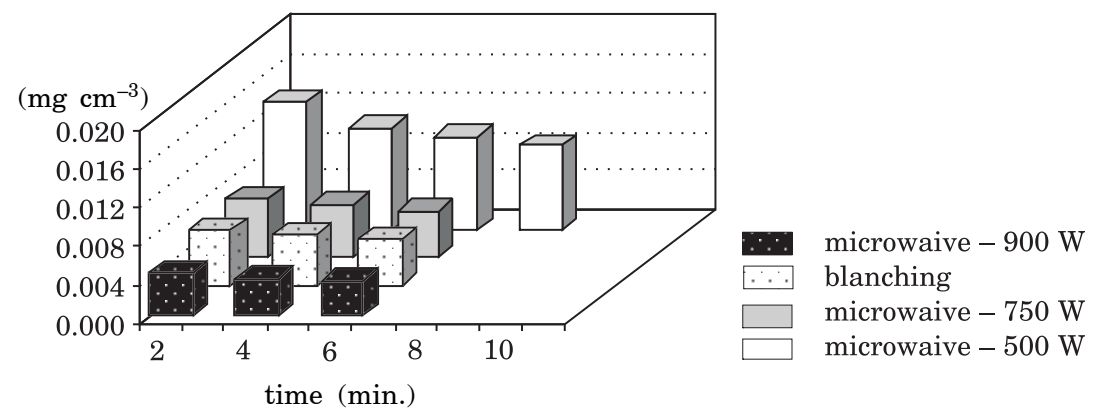

Fig. 1 Peptide content of fractions 3-5 obtained from IMAC chromatography of extracts from string bean (after heating) on $\mathrm{Cu}(\mathrm{II})$-IDA-Sephadex

affinity for both copper and nickel ions were obtained after two minutes of blanching. The fact that these additional fractions were obtained by separation using immobilized nickel ions after two and then after six minutes of blanching may be indicative of conformational changes accompanied by denaturation and partial hydrolysis of molecules. The lowest degree of denaturation was observed in string beans processed with microwaves for 2 minutes at $500 \mathrm{~W}$. The reason for these changes could be the differences in dissociation of fraction $11 \mathrm{~S}$ into subunits with exposure of hydrophobic sur- 


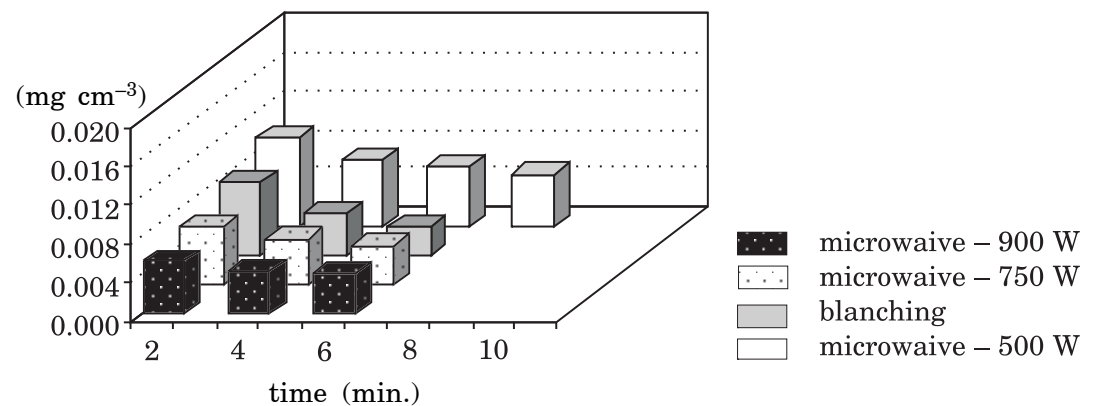

Fig. 2. Peptide content of fractions 3-5 obtained from IMAC chromatography of extracts from string bean (after heating) on Ni(II)-IDA-Sephadex

faces of the $\beta$-conformation of polypeptide chains, which may polymerize or interact with other molecules. After two and four minutes of heating with $500 \mathrm{~W}$ microwaves, the peptide content of fractions 3-7, determined with TNBS, was substantially lower than in blanched samples. Microwaves considerably accelerate the hydrolysis of peptide bonds: two-hour microwave heating of a protein solution in hydrochloric acid produces a comparable quantity of amino acids as traditional 24-hour hydrolysis (KROLL et al. 1998).

Columns with immobilized $\mathrm{Cu}$ ions are often used in the process of protein and peptide separation. They have been applied to selectively purify synthetic peptides containing cysteine and histidine (HANSEN et al. 1996), to separate peptides obtained through casein hydrolysis (LiN et al. 2000), to purify antibodies and their proteolytic/recombinant fragments (RoGUE et al. 2007), and to isolate human immunoglobulin IgG (VANCAN et al. 2002). The process of affinity chromatography involving chelate-bound metal ions is determined by many factors (UEDA et al. 2003). Due to the above, the results obtained in this study are difficult to compare with the findings of other authors. The effectiveness of different metal ions used in a given process can be tested reliably only with the use of the same bed and the same material subjected to separation, under identical elution conditions.

As shown in the fraction images obtained after the separation of extracts from string beans heated in a microwave oven, the largest peak was observed for fractions 3-5 irrespective of the heating time, microwave power and the type of metal ions immobilized on the column (Figures 3-6). The application of $750 \mathrm{~W}$ and $900 \mathrm{~W}$ microwaves for more than six minutes led to the surface drying and browning of string beans, which lost their nutritional value. The levels of peptides were affected by all the tested factors. The highest peptide content (expressed as the leucyl-glycine content) was noticed after microwave heating at the lowest power $(500 \mathrm{~W})$ for the shortest time (2 minutes). Larger amounts of peptides were determined in fractions obtained by separation with the use of immobilized $\mathrm{Cu}$ ions $\left(0.0132 \mathrm{mg} \mathrm{cm}^{-3}\right)$, compared with $\mathrm{Ni}$ ions $\left(0.0093 \mathrm{mg} \mathrm{cm}^{-3}\right)$. Similar results were reported after microwave heating at $750 \mathrm{~W}$ (Figures 1, 2). 


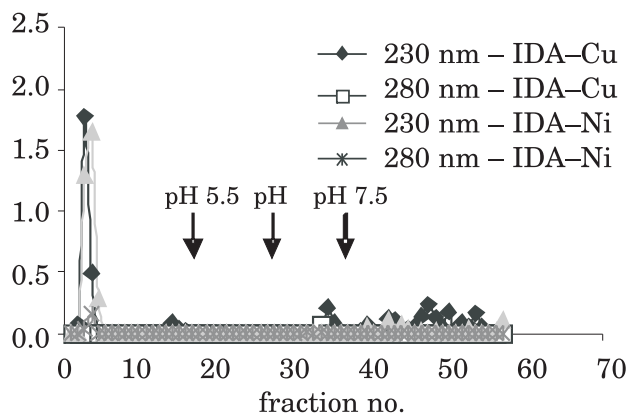

$b$

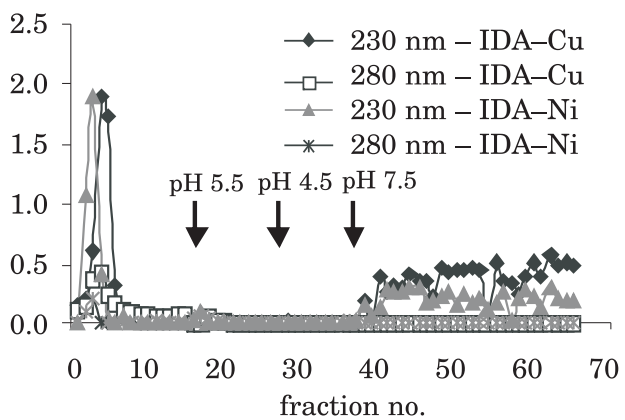

Fig. 3. Elution profiles of non-bound peptides from IMAC chromatography of extracts from string bean (blanching: $a-2$ min., $b-6$ min.) on $\mathrm{Cu}(\mathrm{II})-\mathrm{IDA}-\mathrm{Sephadex}$ and $\mathrm{Ni}(\mathrm{II})$-IDA-Sephadex

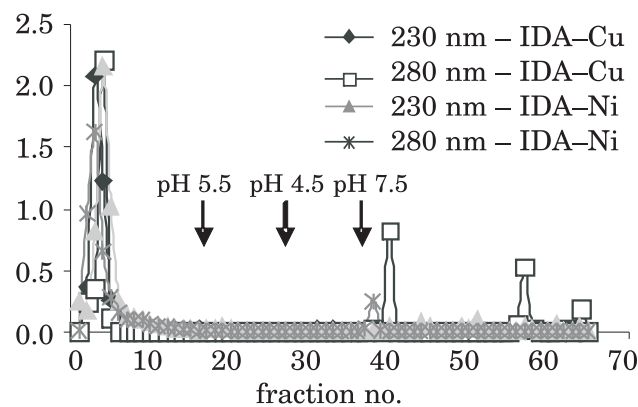

$b$

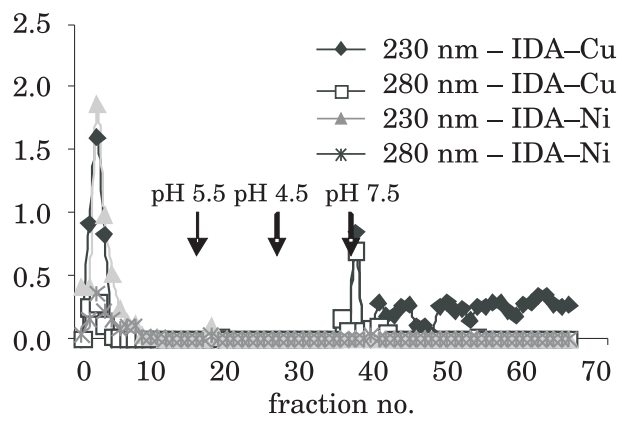

Fig. 4. Elution profiles of non-bound peptides from IMAC chromatography of extracts from string bean (microwave-heating $500 \mathrm{~W}: a-2$ min., $b-6 \mathrm{~min}$. on $\mathrm{Cu}(\mathrm{II})-\mathrm{IDA}-$ Sephadex and $\mathrm{Ni}(\mathrm{II})$-IDA-Sephadex

$a$

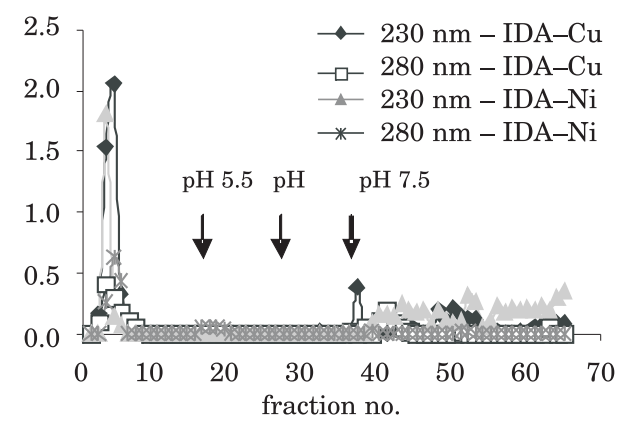

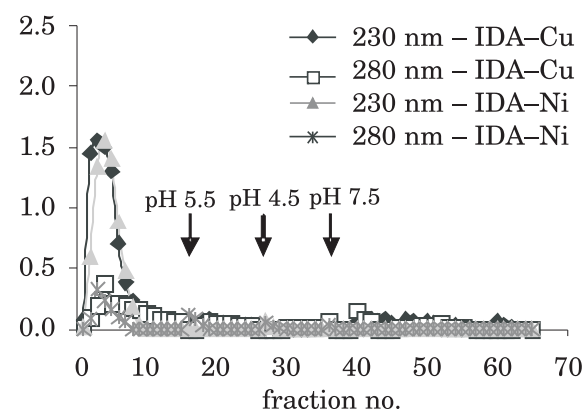

Fig. 5. Elution profiles of non-bound peptides from IMAC chromatography of extracts from string bean (microwave-heating $750 \mathrm{~W}: a-2$ min., $b-6$ min.)

on $\mathrm{Cu}(\mathrm{II})$-IDA-Sephadex and $\mathrm{Ni}(\mathrm{II})$-IDA-Sephadex 


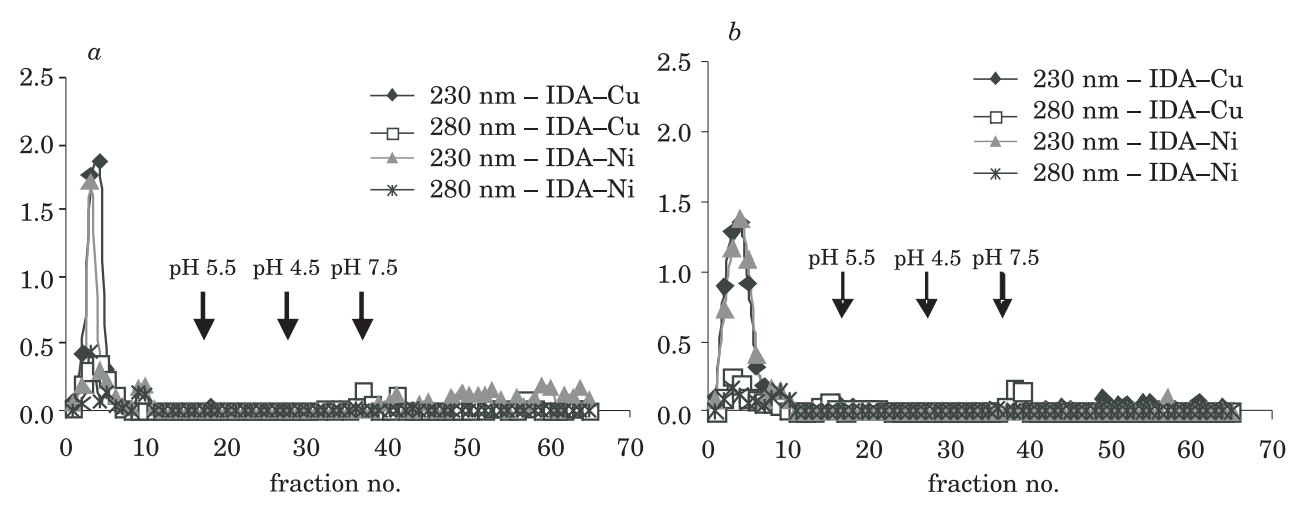

Fig. 6. Elution profiles of non-bound peptides from IMAC chromatography of extracts from string bean (microwave-heating $900 \mathrm{~W}: a-2 \mathrm{~min} ., \quad b-6 \mathrm{~min}$. ) on $\mathrm{Cu}(\mathrm{II})$-IDA-Sephadex and Ni(II)-IDA-Sephadex

At higher microwave power $(900 \mathrm{~W})$, peptide content obtained by separation on columns with immobilized $\mathrm{Ni}$ ions was higher than that obtained with $\mathrm{Cu}$ ions $\left(0.0054 \mathrm{mg} \mathrm{cm} \mathrm{cm}^{-3}\right.$ vs. $\left.0.0042 \mathrm{mg} \mathrm{cm}^{-3}\right)$. The peptide content determined with TNBS in fractions obtained by separation with both $\mathrm{Cu}$ and $\mathrm{Ni}$ ions decreased as the time of blanching was prolonged. Regardless of the blanching time and the type of metal ions used, fractions 3-5 contained the largest amounts of peptides (expressed as leucyl-glycine content) - Figures 1,2 . In the extract of string beans blanched for two minutes, the peptide content was higher following the application of $\mathrm{Ni}$ ions $\left(0.00758 \mathrm{mg} \mathrm{cm} \mathrm{cm}^{-3}\right)$

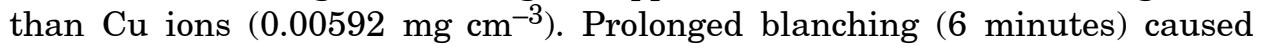
a 2.5-fold and a 1.2-fold decrease in the peptide content of these fractions after separation using immobilized $\mathrm{Ni}$ and $\mathrm{Cu}$ ions, respectively (Figure 3). Very small peaks with an insignificant peptide content were detected with respect to samples blanched for 8 and 10 minutes. Following separation with the use of immobilized $\mathrm{Cu}$ ions, a small peak was observed for fractions 38-39 in samples heated for 4, 6, 8 and 10 minutes, with a peptide content of $0.0025,0.0037,0.0033$ and $0.0071 \mathrm{mg} \mathrm{cm}^{-3}$ respectively.

LIESIENÉ et al. (1997) obtained a fraction image identical to that reported in this study after separation in columns with immobilised copper ions on a cellulose bed. The application of a $0.5 \mathrm{M}$ solution of sodium chloride in a phosphate buffer at $\mathrm{pH}=7.8$ enabled us to achieve the maximum protein content (measured spectrophotometrically, $\mathrm{A}_{280}$ ) already in the first fractions. Further elution with an acetate buffer at $\mathrm{pH}$ from 6.6 to 4.3 produced several small peaks with a maximum absorbance below 0.1 .

In the process of isolating green fluorescent protein (GFPuv), the highest efficiency was reported for copper ions, followed by nickel ions, while the lowest efficiency was noted for zinc and cobalt ions (LI et al. 2001). VARLAMOv et al. (1995) recommended the use of IDA-Sepharose with immobilized Co ions at the final purification stage of beta-dopamine hydroxylase 
from beef bone marrow adrenaline, owing to more effective interactions with these ions, compared with copper, zinc and nickel ions. Cobalt ions also proved to be more selective than $\mathrm{Cu}, \mathrm{Ni}, \mathrm{Zn}$ and $\mathrm{Cd}$ ions during the purification of selenoprotein $\mathrm{P}$ from human plasma (SIDENIUS et al. 1999), despite stronger interactions between proteins and nickel ions.

Peptides found in string beans had similar affinity for metal ions in the $\mathrm{Cu}>\mathrm{Ni}$ sequence, with selectivity in the $\mathrm{Ni}>\mathrm{Cu}$ order (Figured 3-6).

When analysing the affinity of two synthetic ATPase N-terminal peptides from Helicobacter pyroli. Volz et al. (1998) observed that nickel ions are more effective in binding peptides containing histidine residues, while copper ions are more likely to interact with peptides containing cysteine residues. ZACHARIOU and HEARN (2000) suggested mixed-type interactions of proteins and peptides with metal ions - in addition to the formation of coordinate bonds, which are largely responsible for the formation of permanent bonds, they are also responsible for electrostatic interactions whose stability is determined by the eluent's $\mathrm{pH}$ and ionic strength. The effect of the latter factor should be excluded in this study, because the elution process was conducted with the use of the same buffer at an identical concentration.

PATWARDHAN and AtAAI (1997) postulated the existence of two types of copper ions inside the matrix, which are marked by variable availability for protein molecules diffused through the column. According to the above authors, at higher $\mathrm{pH}$ values, proteins are bound to easily available copper ions and are first to be eluted, while at lower $\mathrm{pH}$ values the eluted proteins are proteins bound to less available copper ions. According to JoHNsON et al. (1996), in an alkaline environment, histidine and lysine - amino acids coordinated via the amino groups - are not bound to metal ions but to the solid support, and the process resembles ion-exchange chromatography, while in an acidic environment these amino acids form strong coordinate bonds with metal ions, and the process is analogous to affinity chromatography.

\section{CONCLUSION}

1. Microwave heating of string beans decreases the peptide content of extracts isolated with $1 \%$ TCA. The resulting changes are dependent on the duration of the process and the type of heating medium.

2 Peptides found in string beans had similar affinity for metal ions in the $\mathrm{Cu}>\mathrm{Ni}$ sequence, with selectivity in the $\mathrm{Ni}>\mathrm{Cu}$ sequence.

3. Affinity chromatography with the use of metal ions immobilized to iminodiacetic acid (IDA)-Sephadex G-25 may be successfully used for the separation of peptides isolated from string beans. 


\section{REFERENCES}

AdLER-Nissen J. 1979. Determination of the degree of hydrolysis of food protein hydrolysates by trinitrobenzenosulfonic acid. J. Agric. Food Chem., 27:1256-1262.

Bosiacki M., Tүкsiśski W. 2009. Copper, zinc, iron and manganese content in edible parts of some fresh vegetables sold on markets in Poznań. J. Elementol., 14(1): 13-22.

ChaGa G. 2001. Twenty five years of immobilized metal ion affinity chromatography: past, present and future. J. Biochim. Biophys. Methods, 49: 313-334.

НАВEEв A. 1966. Determination of free amino groups in proteins by trinitrobenzenosulfonic acid. Anal. Biochem., 14: 328-336.

Hansen P., Andersson L., Lindeberg G. 1996. Purification of cysteine-containing synthetic peptides via selective binding of the á-amino group to immobilized $\mathrm{Cu}^{2+}$ and $\mathrm{Ni}^{2+}$ ions. J. Chromatogr., 723: 51-59.

Johnson R., Todd R., ARnold F. 1996. Multipoint binding in metal-affinity chromatography. Effect of $p H$ and imidazole on chromatographic retention of engineered histidine-containing cytochromes $c$. J. Chromatogr., 725: 225-235.

Kroll J., RAwel H., KRöCK R. 1998. Microwave digestion of proteins. Z Lebensm Unters Forsch A, 207: 202-206.

Li Y., Agrawal A., Sakon J., Beitle R. 2001. Characterization of metal affinity of green fluorescent protein and its purification through salt promoted, immobilized metal affinity chromatography. J. Chromatogr., 909: 183-190.

Liesienë J., Račaitytë K., Morkevičienë M., Valančıus P., Bumelis V. 1997. Immobilized metal affinity chromatography of human growth hormone. Effect of ligand density. J. Chromatogr., 764: 27-33.

Lin F-Y., Chen W-Y., Huang S-Y. 2000. Selective separation of caseinophospopeptides through immobilized metal ion affinity chromatography: effects of $p H$ values, salt concentrations and degree of phosphorylation. Bioprocess Engin., 23: 467-471.

Patwardhan A., Ataai M. 1997. Site accessibility and the $p H$ dependence of the saturation capacity of a highly cross-linked matrix. Immobilized metal affinity chromatography of bovine serum albumin on Chelating Superose. J. Chromatogr., 767: 11-23.

Roque A. C.A., Silva C.S.O., TaIPA M. A. 2007. Affinity-based methodologies and ligands for antibody purification: Advances and perspectives. J. Chromatogr. A, 1160:44-55.

Senze M, Kowalska-Góralska M., Pokorny P. 2009. Metals in chosen aquatic plants in a lowland dam reservoir. J. Elementol., 14(1):147-56.

Sidenius U., Farver O., Jons O., GammelgaARd B. 1999. Comparison of different transition metal ions for immobilized metal affinity chromatography of selenoprotein $P$ human plasma. J. Chromatogr., 735: 85-91.

SURówKA K. 1994. Mikrofale i ich zastosowanie $w$ technologii żywności [Microwaves and their applicability in food technology]. Żywn. Technol., Jakość, 1: 13-20. (in Polish)

Ueda E., Gout P., Morganti L. 2003. Current and prospective applications of metal ionprotein binding. J. Chromatogr., 988: 1-23.

Vancan S., Everson M., Bueno S. 2002. IMAC of human IgG: studies with IDA- immobilized copper, nickel, zinc, and cobalt ions and different buffer systems. Proc. Biochem., 37: 573-579.

Varlamov V., Lopatin S., Ilyja A., Bannikova G., Chlenov M. 1995. New approaches to chroma-

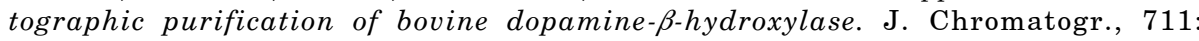
113-118. 
Volz J., Bosch F., Wunderlin M., Schuhmacher M., Melchers K., Bensch K., Steinhilber W., Schäfer K., Tóth G., Penke B., Przybylski M. 1998. Molecular characterization of metal binding polypeptide domains by electrospray ionization mass spectrometry and metal chelate affinity chromatography. J. Chromatogr., 800: 29-37.

Zachariou M., Hearn M. 2000. Adsorption and selectivity characteristics of several human serum proteins with immobilized hard Lewis metal ion-chelate adsorbents. J. Chromatogr., 890: 95-116. 